Dossiê

\title{
Perspectivas tecnoxamânicas e tecnomágicas no ativismo digital brasileiro recente: uma trajetória possível
}

Adriano Belisário Feitosa da Costa²

Pedro P. Ferreira ${ }^{3}$

Resumo: Este texto aborda a multiplicidade de sentidos do tecnoxamanismo e da tecnomagia no discurso e na prática de ciberartistas/ativistas brasileiros contemporâneos entre 2002 e 2015. Partindo de experiências como a das redes Metareciclagem, Submidialogia e Mídia Tática, apresentamos a emergência da ideia de tecnoxamanismo/magia em debates, eventos e redes do ativismo digital brasileiro. $\mathrm{O}$ resultado deste trajeto é uma imagem múltipla e contraditória de práticas, vividas como libertárias e transformadoras, envolvendo visões não-instrumentais e não-antropocêntricas da técnica.

Palavras-chave: ativismo; arte; tecnoxamanismo; tecnomagia; antropofagia.

1 A pesquisa que resultou neste artigo foi financiada pela CAPES, a quem agradecemos. Este texto corresponde a uma versão retrabalhada das seções 3.4 e 3.5 de Belisário (2016a).

2 MediaLab/Universidade Federal do Rio de Janeiro (UFRJ) - Rio de Janeiro - Brasil - adrianobf@gmail.com

3 LaSPA-CTeMe/Universidade Estadual de Campinas (UNICAMP) - Campinas - Brasil - ppf@unicamp.br 


\section{Technoshamanic and technomagic perspectives in recent brazilian digital activism: one possible trajectory}

ABSTRACT: This paper aproaches the multiplicity of meanings that technoshamanism and technomagic have in the discourse and practice of contemporary brazilian ciberartists/activists between 2002 and 2015. Starting with experiences such as the Metareciclagem, Submidialogia and Mídia Tática networks, we present the emergence of the idea of technoshamanism/magic in debates, events and networks of brazilian's digital activism. The result of this trajectory is a multiple and contradictory panorama of practices, lived as libertarian and transformative, involving non-instrumental and non-anthropocentric visions of techniques.

KEYWORDS: activism; art; technoshamanism; technomagic; anthropophagy.

Os tecnoxamãs do presente parecem encarnar o homem natural tecnizado de Oswald, são sua imagem mais bem acabada. Os novos alquimistas do século XXI restituem à brincadeira e ao encantamento sua prioridade, a um só tempo, ontológica e epistemológica. A técnica [...] é agora hackeada, desmontada e remontada em um contexto no qual os valores patriarcais de eficácia, produtividade e competitividade são constantemente colocados sob suspeita. (Vidal Jr., 2016: 57-8).

Este texto busca abordar a multiplicidade de sentidos do tecnoxamanismo e da tecnomagia ${ }^{4}$ no discurso e na prática de ciberartistas/ativistas brasileiros contemporâneos entre 2002 e 2015. Buscaremos fazer isso não a partir de um olhar neutro sobre uma realidade, mas cientes de que nossa perspectiva implica um recorte ativo, com seus próprios pontos cegos. Trata-se de um percurso entre muitos, um percurso guiado pelo interesse em acompanhar como se relacionam magia, tecnologia e xamanismo em eventos e processos concretos envolvendo movimentos estético-políticos brasileiros ligados às tecnologias digitais. Não nos interessa a busca pela "origem" do tecnoxamanismo ou da tecnomagia. A emergência destas práticas e ideias não foi produzida a partir de indivíduos que, de uma só vez, as expressam e definem. Não há um fato histórico, uma pessoa, um sentido originário ou uma única linha contínua de causalidades espaço-temporais capaz de explicar esta emergência. São, antes, sucessivas interpretações e

4 Os termos "tecnomagia" e "tecnoxamanismo", apesar de possíveis diferenças (por exemplo, a ênfase mais forte do primeiro na alquimia e no ocultismo, e do segundo em práticas indígenas), serão usados como sinônimos neste artigo, por, em grande medida, serem assim usados nos discursos e práticas aqui trabalhados. 
encontros, esquecimentos, tradições e rupturas. As perspectivas aqui apresentadas são, portanto, uma trajetória possível dentre outras.

\section{Deglutindo o digital}

$\mathrm{O}$ ano de 2002 foi importante para as ideias e práticas envolvendo as relações entre magia e cibercultura na então recém-nascida cultura hacker brasilei$\mathrm{ra}^{5}$. Foi naquele ano que surgiu o Rizoma.net: mais que um site ou uma revista virtual, conforme sua própria definição, tratava-se de uma verdadeira "máquina de conceitos", que organizou, traduziu e publicou diversos trabalhos sobre afrofuturismo, conspirologias, neuropolíticas, recombinação, hierografia, anarquitexturas e outros temas. ${ }^{6}$ Outra importante iniciativa também surgida naquele ano foi o projeto Metá:Fora, que funcionou até 2003, principalmente por meio de uma lista de discussão aberta (Caetano, 2006: 205-7). No início, o grupo reunia principalmente "integrantes de outras listas brasileiras sobre marketing e comunicação", mas em pouco tempo se expandiu para incorporar pessoas com formações e experiências nas áreas de "comunicação, tecnologia, educação e arte" (Caetano, 2006: 207). Mais do que discussões sem fim, segundo o pesquisador e artista Hernani Dimantas (2006), a ideia era criar uma "chocadeira colaborativa" para projetos e ações.

Nas palavras do participante identificado como Tupi Namba, entrevistado por Miguel A. Caetano (2006: 206), o discurso inicial no Metá:Fora se assemelhava a um "empreendedorismo geek flower power de Silicon Valley" e a um "anarquismo do período punk". O diálogo com a cultura mercadológica também era visível em outros processos, como no uso intensivo, pelos participantes, do termo "caordem" para definir o processo de organização no qual, a partir do

5 Antes de 2002, vale destacar os textos reunidos no livro Memórias do neto de Dacum, o aborígene - outrora intitulado ciber\%amanismo, assinado por Olav Swenson (2014), heterônimo de Eduardo Pinheiro (Padma Dorje), e publicado em 1997. De acordo com o próprio autor, o livro é uma "versão estritamente pós-moderna" e "desbragadamente charlatã" de manuais alquímicos que incorporavam elementos de "cabala, thelema [...], psicologia de almanaque e misticismo quântico", escrito a partir de "sonhos, visões e sincronicidades" compartilhadas com o escritor Daniel Pellizzari (Eduardo Pinheiro, apud Gitti, 2013).

6 A Rizoma.net existiu entre 2002 e 2009 e sagrou-se como uma referência para o pensamento crítico e provocativo da cultura digital brasileira. Segundo a pesquisadora e ativista Giseli Vasconcelos (apud Belisário, 2016a: 120), a revista era organizada por "um grupo pequeno, com alguns colaboradores, geralmente tradutores, mais ligados à ficção científica e ao ocultismo," dentre os quais cabe destacar o ciberartista e ativista Ricardo Rosas. Merece especial atenção a edição intitulada "Ocultura”, de agosto de 2002. Nela, entre outros materiais, é possível encontrar um ensaio de Timothy Leary descrevendo o cyberpunk como alquimista moderno; um artigo de Erick Felinto sobre 'tecnognose', em que se exploram as relações entre tecnologias do virtual e a imaginação espiritual; três trabalhos de Hakim Bey sobre aspectos místicos das lutas políticas; além de um texto de Daniel Pellizzari sobre magia do caos e discordianismo. 
caos aparente das conversas na lista de discussão, emergiam ações e projetos colaborativos, mais ou menos ordenados em seus propósitos. Ainda que tenha sido reapropriado para designar também o processo auto-organizativo de mutirões e do carnaval, Daniel Hora (2010: 110) nota que o termo foi "deglutido (em termos antropofágicos) do discurso mercadológico sobre a cooperação de agentes independentes em torno de uma finalidade comum".

Segundo Caetano (2006: 206), de início a ênfase tecnológica das conversas na lista do projeto Metá:Fora evidenciava "um certo pendor para o tecnonarcisismo que, como Matteo Pasquinelli acusa [...], predomina em muitos projetos autônomos trabalhando com mídia e tecnologia”. Aos poucos, porém, com os diálogos e a ampliação de participantes com experiências e trajetórias de vida diferentes, o foco passou "da atenção sobre a tecnologia em si para uma maior consciencialização sobre as necessidades reais das pessoas comuns”. Diversas ações foram realizadas ou idealizadas a partir do Metá:Fora (cf. Dimantas, 2006: 42-3), dentre as quais destacamos a "rede Metareciclagem".

A ideia da metareciclagem surgiu a partir de uma provocação do ciberartista/ ativista Daniel Pádua, em julho de 2002, na lista do Metá:Fora, para a criação de uma rede local sem fio, independente da Internet, "usando placas WiFi de segunda mão, antenas repetidoras feitas com latas de batatas Pringles" e computadores reciclados rodando softwares livres para servirem de pontos de acesso em escolas públicas e associações comunitárias (Caetano, 2006: 226): "criando um 'backbone de lixo' usando Wi-fi dá pra pelo menos conectar você com aqueles seus amigos lá do outro lado da cidade. Porque o lance nem é a Internet, mas a criação de uma rede local" (Metá:Fora, 2009: 31). Em janeiro de 2003, já sob o nome de "Metareciclagem", mas ainda como subprojeto do Metá:Fora, alguns membros ativos da rede já ocupavam uma sala em São Paulo para receber computadores usados ou quebrados, triar as peças, montar novas máquinas e instalar softwares livres. No início, o trabalho com metareciclagem lidava principalmente com a manipulação de hardwares considerados obsoletos, lixo eletrônico, para dar-lhes novos significados, por meio de desmontagens e remontagens, a fim de estimular a apropriação das novas tecnologias. Em março de 2003 o Metareciclagem fez sua primeira participação em um evento público, somando-se a outros coletivos na construção do Festival de Mídia Tática Brasil (MTB). ${ }^{7}$

7 A ideia de "mídia tática" foi formulada originalmente em um manifesto assinado por David Garcia e Geert Lovink (1997) e publicado na lista digital Nettime (cf.: <http://nettime.org/>), criada por Lovink e Pit Schultz para fomentar um debate europeu capaz de fazer frente às ideias ventiladas pelos ciber-utópicos californianos (cf. Lovink, 1998). A Nettime se contrapunha diretamente ao que John P. Barlow (1996) chamava de "ciberespaço" e à contracultura cibernética norte-americana. A ideia de mídia tática 
O Festival MTB, realizado em São Paulo em 2003, atraiu bastante atenção, inclusive da grande mídia, em parte por conta da presença de personalidades, como o então recém nomeado ministro da cultura Gilberto Gil, o ciberativista e fundador da Electronic Frontier Foundation (EFF) John Perry Barlow e os pesquisadores Richard Barbrook, Peter Pál Pebart, Suely Rolnik, entre outros. ${ }^{8} \mathrm{~A}$ respeito do MTB, David Garcia comentou na lista do Nettime:

O processo começou quando um grupo de três ativistas baseados em São Paulo, Giseli Vasconcelos, Tatiana Wells e Ricardo Rosas, responderam a um pedido para que alguém hospedasse um "laboratório de mídia tática" na América Latina. O convite foi postado em várias listas (mais por esperança do que por expectativa) pelos organizadores do Next 5 Minutes, festival de Mídia Tática de Amsterdam. Laboratórios de mídia tática foram feitos ao redor do mundo, com graus variados de sucesso. Eles eram um elemento-chave da tentativa do Next 5 Minutes de ampliar e de alargar sua área de atuação e descentralizar seu processo editorial. No evento, o laboratório de mídia tática brasileiro se tornou mais um festival do que uma oficina, atraindo quase quatro mil visitantes e considerável cobertura midiática. Mas mais importantes do que o número de visitantes foram as potentes novas redes de possibilidades e de ação que brotaram através das divisões culturais e sociais de São Paulo, e que continuam a dar frutos. Tudo isso é ainda mais impressionante quando se percebe que o Laboratório de Mídia Tática de São Paulo foi literalmente um "festival sem financiamento". (Garcia, 2004, p.2)

Em agosto de 2003, um segundo núcleo da Metareciclagem foi ativado, em parceria com a Prefeitura de Santo André, pelos pesquisadores e artistas Dalton Martins, Hernani Dimantas e Glauco Paiva. Artista local, Paiva customizava as máquinas com pinturas, prática que se tornou uma importante característica da metodologia de metareciclagem, apontada para uma preocupação estéticocriativa na relação com a tecnologia, para além do mero uso instrumental. Outra característica fundamental dessa metodologia, presente desde cedo, é a visão

se fortaleceu também na série de festivais Next Five Minutes ( $\mathrm{N}_{5} \mathrm{M}$ ) de arte, política, ativismo e mídia, realizados em Amsterdã entre 1993 e 2003 com artistas e ativistas dos Estados Unidos e da Europa, incluindo dissidentes e ativistas Samizdat da ex-URSS (cf. Clinio, 2013: 170). Apesar de refratários à estética sessentista e ao discurso ciberutópico, os intelectuais europeus pareciam abertos a outras ideias oriundas da "contracultura cibernética", como a cultura hacker e o uso de softwares livres.

8 Inicialmente articulado a partir da lista do Metá:Fora, o Festival MTB chamou a atenção de Gilberto Gil, que pediu para participar da abertura, trazendo também John Perry Barlow, que havia sido convidado pelo Ministério da Cultura (MinC) para passar o carnaval no Brasil.

Todos os textos em outros idiomas foram traduzidos pelos autores. 
crítica com relação à noção de "inclusão digital", predominante nas políticas públicas de tecnologia da informação para a sociedade civil. ${ }^{10}$ Apesar de não serem opostos à inclusão digital (cf. Caetano, 2006: 244-7), muitos dos colaboradores da Metareciclagem preferiam trabalhar com a noção de "reapropriação social da tecnologia”. Nesse sentido, em sua apresentação no festival Next Five Minutes de 2003, Felipe Fonseca evoca a tradição antropofágica brasileira, ${ }^{11}$ ao definir sua concepção de "cultura hacker brasileira" com base na produção colaborativa e na liberdade da informação:

Alguns dos exemplos que eu usei pra ilustrar [...] [isso] foram a umbanda (policêntrica, adaptada a cada localidade, sem um dogma ou autoridade fixas), a Antropofagia e a Tropicália, e os camelôs e o comércio de rua. Outros exemplos [...] eram a feijoada, o trabalho colaborativo na escola de samba, o mutirão pra pintar as paredes de casa, e por aí vai. (Fonseca, 2008: 94).

O festival Digitofagia, organizado pelos ciberartistas/ativistas Giseli Vasconcelos, Lucas Bambozzi, VJ Pixel, Ricardo Ruiz, Sandra Terumi e Tatiana Wells, em outubro de 2004, em São Paulo e no Rio de Janeiro, aprofundou mais diretamente esse diálogo com a antropofagia:

A concepção de Digitofagia foi pensar uma prática antropofágica que reatualizasse esse ideário no contexto da cultura digital, reabastecendo seu viés libertário. Para tanto, abraçar práticas espontâneas na cultura contemporânea brasileira, como a pirataria, os camelôs e a gambiarra, seria, quem sabe, uma forma de trazer a mídia tática para um campo mais familiar e mais cotidiano aos praticantes, teóricos e ativistas brasileiros. (Rosas e Vasconcelos, 2006: 11).

10 Esta noção pode ser observada em ação na seguinte passagem do discurso de Gil no MTB, quando ele coloca uma questão para Barlow e Barbrook: "É possível imaginar um cenário onde a maioria da população de países como o Brasil, ainda submersas nos problemas da desigualdade e da fome, deixem de ser apenas espectadoras atrasadas dos benefícios das inovações ciberculturais? Ou a tendência é uma cada vez maior separacão entre ricos (cibercomunistas ou não) e pobres, sempre sem conexão, ou sem a boa conexão?". Um registro em vídeo desta fala pode ser encontrado entre os minutos 13 e 14 de: <https:// www.youtube.com/watch?v=UhGLFaE9jjE >. Acesso em: 06 out. 2016.

11 No discurso antropofágico, a começar pela obra do próprio Oswald de Andrade (1972), mas também em movimentos influenciados por ela, como o Kaos de Jorge Mautner e os concretistas, observamos muito precocemente a formulação explícita de tensões e associações fundamentais para o tecnoxamanismo e para a tecnomagia, como diversos paralelos precoces com o discurso cibernético e a ênfase na noção de "bárbaro tecnizado" (cf. Belisário, 2016a: 104-12). 
Além de debates sobre mídia tática e críticas à propriedade intelectual, a programação do Digitofagia contava com uma rádio livre, mostras artísticas, oficinas de instalação de Linux, produção com software livre, entre outras atividades (cf. Clinio, 2011: 69-75). O evento resultou em duas publicações, ${ }^{12}$ uma delas (Rosas e Vasconcelos, 2006) tendo sido considerada uma "antologia da mídia tática brasileira” pelo pesquisador e ativista inglês Geert Lovink (2009). A "deglutição do digital” implicada no título do evento tinha, para os organizadores, uma conotação claramente tecnoestética, sintetizada na reciclagem de tecnologia obsoleta, como expressou Wells (apud Belisário, 2016a: 126), uma das organizadoras do evento: a prática da digitofagia é "nosso ritual 'branco', mas necessário, de decrescer a tecnologia; a tão necessária 'vingança do low-tech' que [Ricardo] Rosas apregoava. Eu chamo isso de antidesenvolvimentismo, uma recusa necessária (afinal nunca fomos modernos)”.

Rosas (2006: 47) considerava a prática da gambiarra como "endêmica" no Brasil, apesar de pouco teorizada. ${ }^{13}$ De fato, não seria a gambiarra um arranjo técnico devorador por excelência, uma "antropofagia da técnica" em ato? A gambiarra é uma prática aberta. Há nela sempre algo a se terminar, ajustar ou acrescentar. Há uma força centrípeta no processo de individuação da gambiarra, onde todos os outros objetos ao redor são devorados, descodificados e reterritorializados em novos arranjos. Produção e consumo se mesclam, confluem. A gambiarra é um “prodossumo", poderia dizer Décio Pignatari (2004). Antes dos hackers, já tínhamos a gambiarra - parece-nos dizer Rosas (2006), ao estilo de Oswald de Andrade (1972).

$\mathrm{O}$ que se percebe na mídia tática, na afirmação positiva da gambiarra, na metareciclagem ou em outras redes da cultura digital brasileira dos anos 2000, 14 é que todas essas abordagens são consideradas antropofágicas na medida em que enfatizam a apropriação crítica das tecnologias em um presente urgente. Com discurso fundamentalmente crítico à tecnocracia, estimula-se uma

12 O Digitofagia cu-que-buquê (Cook book), publicação online editada por Wells e Ruiz (2006) com as discussões preparatórias para o evento; e o livro Net_cultura 1.0: Digitofagia, coorganizado por Rosas e Vasconcelos (2006).

13 Rosas (2006: 39) aproxima, em certo momento, a gambiarra do conceito de bricolagem, formulado por Lévi-Strauss (1989: 32-7), pois diferentemente da engenharia, a relação com os objetos técnicos estabelecida pela prática da gambiarra não se submeteria a um projeto predefinido transcendente à prática do fazer, antes operando pela imanência em uma recombinação constante, um processo mais que um produto final.

14 Como, por exemplo, o Estúdio Livre (cf. Balvedi et al., 2013), o Movimento dos Sem-Satélites (cf. $<$ http://devolts.org/msst/?page_id=2>) e o Submidialogia (cf. <http://submidialogia.org/>). Acesso em: 06 out. 2016. 
apropriação das tecnologias em um contexto de escassez - e não excesso - de recursos. Tais iniciativas são fundamentadas sobre as premissas filosóficas, mas principalmente sobre o uso e o desenvolvimento prático de software livre: aliado às práticas de documentação acessível sobre estas ferramentas e à realização de inúmeras de oficinas, cursos e outras práticas pedagógicas, o caráter prático e ativo dessas "digitofagias" se evidencia. Para além de um academicismo teórico, esses coletivos extraíam as implicações, potencialidades e limitações, ao mesmo tempo teóricas e práticas, das tecnologias digitais, para lidar com processos de diversas naturezas (artísticos, midiáticos-comunicacionais, políticos etc.). Essa ênfase na prática e no ativismo foram centrais para a formulação de um importante discurso sobre "cultura digital" no Brasil, inclusive enquanto política pública federal.

\section{Macropolíticas}

O relativo êxito do Festival MTB e ações posteriores ${ }^{15}$ favoreceram a formação de uma rede para facilitar o intercâmbio de experiências entre pesquisadores, coletivos e ativistas ligados à arte, à mídia e à tecnologia. $\mathrm{O}$ encontro também serviu como ponto de partida para as ações do Ministério da Cultura com novas tecnologias, num diálogo que se manteve em eventos como o Festival MTB, o Fórum Internacional de Software Livre e outros. Como consequência, em 2004, Gil já não falava mais em "inclusão digital", mas em uma "Ação Cultura Digital”, incorporada como um dos pilares das políticas públicas do Programa Cultura Viva, junto com a "Ação Griô"; a "Escola Viva”; e os "Pontos de Cultura".

Os Pontos de Cultura, além de contribuírem para a integração das outras linhas de ação às novas tecnologias digitais de produção de mídia, ao selecionarem, por edital público, organizações culturais comunitárias elegíveis para receber apoios específicos do governo, buscaram descentralizar o investimento em produção cultural no Brasil. ${ }^{16}$ Eles passaram a representar uma inversão em relação à lógica de "levar cultura" à periferia por meio da instalação de infraestruturas físicas. Em vez disso, o MinC passava a se posicionar como um catalisador de uma rede emergente de "Cultura Viva", comprometida com setores até então invisíveis ao radar das políticas culturais, como as populações indígenas, quilombolas, as inúmeras tradições de cultura popular Brasil afora,

15 Com destaque para os Autolabs, dedicados à montagem de estruturas e à realização de oficinas de apropriação tecnológica e produção midiática para jovens da Zona Leste de São Paulo (cf. Clinio, 2011: 67-9). 
além de grupos de periferia urbana, como coletivos de hip-hop (cf. Belisário e Lopes, 2011). Ou seja, nas linhas do Programa Cultura Viva, encontramos tanto a ênfase nas tecnologias digitais livres, como a valorização de saberes e tradições ancestrais.

A partir do Programa, diversos ativistas de mídia tática e software livre aprofundaram contatos e experiências com povos indígenas, quilombolas e outras comunidades tradicionais - o que sem dúvida contribuiu para a hibridização, o diálogo e o atravessamento desses discursos. Conforme relata Adriana Veloso Meireles (2008: 39), que atuava em redes como Mídia Tática, Metareciclagem e Submidialogia, o trabalho na Ação Cultura Digital: "não é somente a troca de conhecimentos brutos e inadaptáveis, mas um absurdo antropofágico, uma deglutição de conhecimentos, de um país que está mais do que acostumado à mestiçagem." Segundo Meireles (2008: 39), durante o contato da equipe da Ação Cultura Digital com os Pontos de Cultura espalhados por todo país, nasceram "elementos híbridos, como computadores grafitados, computambores (tambores digitais) e projetos de Linux em linguagens indígenas. A perspectiva é sempre da troca, não da inclusão ou de salvamento".

Autoproclamando-se um "ministro hacker" e trazendo a questão da tecnologia para o centro do debate sobre cultura, Gilberto Gil parecia não só retomar o ideário oswaldiano de uma cultura antropofágica tecnizada, como aprofundar a própria reflexão crítica sobre a técnica, ao incorporar a filosofia do software e da cultura livre. Obviamente, Gil não fez isso sozinho. A Ação Cultura Digital foi operacionalizada inicialmente por um grupo de "articuladores" e consultores contratados pelo Ministério, muitos deles envolvidos com as ações de mídia tática e metareciclagem. Esta relação entre redes e coletivos de ativismo com o Estado não se deu livre de críticas (cf. Veloso 2006: 236). Assinado por Bartolina Sisa (2011), o "Manifesto para a engenharia reversa das redes" tratou desse contexto de mídia tática, ativismo e cibercultura no Brasil, citando muitas das redes mencionadas aqui, para então introduzir algumas críticas e ressalvas quanto à relação entre ativismo e instituições estatais. Destacamos os seguintes trechos:

No Brasil - cuja apropriação tecnológica se manifesta sempre primeiro através da arte - [o conceito de cibercultura] surge com o visionário Oswald de Andrade e sua utopia antropofágica que descreveu a assimilação da tecnologia moderna com o espírito xamanista da selva (em A crise da filosofia messiânica, de 1950). [...] 'A tecnologia que liberta' (FISL 2008), virou seu mote [do software livre] por aqui, na alegre fusão com a comunidade da esquerda partidária sulista, que adentrou com força o governo Lula, mas por outro 
lado ignorando os nada inovadores e imateriais problemas de desequilíbrio de gêneros ( $1,5 \%$ de desenvolvedorxs de SL são mulheres) ou dicotomias ideológicas [...] Ambos os termos - inclusão e cultura digital - surgiram em um contexto majoritariamente institucional, dentro de escritórios com financiamentos da ONU e PNUD, disseminados maciçamente, formando políticas públicas descontextualizadas, onde quem mais lucrou foram sem dúvida xs "articuladores" e a ItauTech (fornecedora de computadores). Meninos entusiastas do software livre que chegavam de avião às localidades mais remotas para armar o circo (zona estatal temporária) da inclusão digital, muitas vezes chamados de Encontros de Conhecimentos Livres [...]. Não estava mais em questão a autonomia, gênero, as alternativas ao capitalismo massacrante, a colaboração para a produção, a práxis, a continuidade das ações. [...] Em 2008 o termo cultura e mídia livre é totalmente desvirtuado de seu sentido original, livre de instituições, proprietários ou gestores - é seu oposto, recurso disputado por partidos de esquerda, blogueiros progressistas e membros de organizações do terceiro setor, criando termos descolados como 'midialivristas', com manifestos próprios e recursos estatais para fóruns, no entanto sendo articulado por usuários de softwares proprietários e instituições de ensino federais. (Sisa, 2011)

Num contexto de evidentes avanços quanto à atuação Estatal no fomento ao uso livre e criativo das tecnologias digitais, alguns pontos cegos passaram a revelar instâncias de capturas do potencial criativo e transformador das tecnologias digitais. Além disso, no esforço pedagógico de estimular a apropriação das tecnologias em discursos ligados à metareciclagem e a este contexto do fomento estatal à cultura hacker no Brasil, frequentemente falava-se em "abrir a caixa-preta”, iluminá-la, para "desmistificar", por meio de instruções e compreensões racionais, o funcionamento das máquinas. No entanto, a insuficiência desta abordagem logo ficou evidente. Descrita como "Desmistificando o Linux", uma das oficinas realizadas pelo coletivo $\mathrm{IPe}^{17} \mathrm{em} 2005$ levou o pesquisador e ciberativista Francisco Caminati (apud Fonseca, 2007) a fazer a seguinte provocação: "vocês e essa mania iluminista de desmistificar as coisas!!! software livre é magia!!!", citando em seguida um trecho de Eduardo Viveiros de Castro sobre o

17 O coletivo carioca IPê (também conhecido como IP://), foi mantido inicialmente por Tatiana Wells, Ricardo Ruiz, Giuliano Djahjah e Floriano Romano, tendo como base um espaço na Lapa (Rio de Janeiro). O nome "IPê" é um jogo de palavras com o Protocolo da Internet, o título 'Interface Pública' e a árvore ipê. Um vídeo de 2012 sobre o coletivo pode ser acessado em: <https://vimeo.com/48886615>. 
xamanismo como prática de subjetivação, ${ }^{18}$ para concluir: "abaixo o fetiche da desmistificação!!!! [...] pela politização do mito [...] glauber rocha”. "Tecnomagia”, respondeu Felipe Fonseca (2007), que depois criou um blog com o mesmo nome para reunir referências e publicar ideias sobre o assunto. ${ }^{19}$

\section{Emergências tecnoxamânicas/mágicas}

Um certo movimento de desvio dessas capturas instrumentais de práticas inovadoras em tecnologias digitais pode ser acompanhado num comentário de Tatiana Wells sobre o "tecnotribalismo" emergente nos encontros Submidialogia: ${ }^{20}$

A primeira vez que ouvi falar em Tecnomagia foi ainda na lista da Metareciclagem, onde se falava de tantas coisas, cada uma mais dispersa que a outra, e estranhamente tudo convergia. Eu lembro do Felipe Fonseca falando sobre isso. Mas foi somente no Submidialogia\#2, em Olinda, que entendi melhor. Porque a gente gostava de ritualizar as coisas, de criar um sentido próprio pras oficinas, transformá-las em recital, performance, rádio... Essa foi a história da Submidialogia, e no \#2 isso foi muito presente com a Oficina de Choque Coletivo ${ }^{21}[\ldots]$, as limonadas sonoras de Glerm, onde os objetos viviam, tinham voz e cor próprias... isso foi aprofundado no \#3 com a Metasubcibertrans da Fabi[ane Borges] e as interatividades de [Ricardo] Brazileiro. (Tatiana Wells, apud Belisário, 2016a: 130-1)

Em fóruns, blogs e textos pelo ciberespaço, a ideia de que as tecnologias digitais são a encarnação contemporânea de potências mágicas se tornou cada vez

18 Vale citar as últimas frases da passagem citada por Caminati: "Sejamos objetivos? - Não! Sejamos subjetivos, diria um xamã, ou não vamos entender nada." (Viveiros de Castro, 2002: 488).

19 Cf.: <https://tecnomagxs.wordpress.com>. Última postagem em janeiro de 2013.

20 Após uma primeira edição realizada em Campinas (SP), em 2005, com atividades sediadas na Unicamp e um formato mais próximo ao de eventos acadêmicos, em sua segunda edição, realizada no ano seguinte em Olinda (PE), o Submidialogia "tornou-se um festival aberto, com discussões, mostras de vídeos e fotos, laboratórios de produção de rádio, TV e internet" (Brunet, 2008: 7). "Submidialogia 2 foi quando a gente abandonou o modelão debate vs. auditório e assumiu a pegada festa tribal na escada, debates espontâneos e a democracia de quem grita mais alto" (Fonseca, 2008: 102). A terceira e quarta edições foram realizadas em 2007, em Lençóis (BA), e em 2009, em Belém (PA), durante o Fórum Social Mundial (Clinio, 2011: 71-2). Se até então os encontros eram feitos de forma bastante espontânea e com pequenos apoios, a situação mudou em 2010, com as derradeiras três edições, executadas com o apoio da Petrobras, em comunidades indígenas (Arraial d’Ajuda-BA, entre 26 e 30 de maio), quilombolas (Mirinzal-MA, entre 26 e 30 de julho) e caiçaras (Ilha dos Valadares, Baía de Paranaguá-PR, entre 4 e 8 de setembro). Cf.: $<$ http://br.submidialogia.org/>. Acesso em: 06 out. 2016.

21 Um vídeo da oficina de choque coletivo pode ser encontrado em: <https:/www.youtube.com/ watch?v=ZgsTVeAPHFE $>$. Acesso em: 06 out. 2016. 
mais recorrente no início deste século (cf. Davis, 1999; Felinto, 2005). No contexto das redes de ativismo e tecnologias digitais no Brasil, essa ideia também foi ganhando força a partir de termos como "tecnomagia" e "tecnoxamanismo". Felipe Fonseca (apud Belisário, 2016a: 132-3), por exemplo, lembra "a garotada da Taina ${ }^{22}$ afirmando que o tambor foi a primeira internet" ${ }^{23}$, sua própria "experiência em terreiro" e também seu "cotidiano de acompanhar e fazer esporos de metareciclagem, que até 2006 tinha uma pegada bem mão na massa, e essa sensação de manipular construções que eram ao mesmo tempo simbólicas e concretas". Essa interação entre o material e o simbólico aparecia, para Fonseca, carregada de magia:

Começaram a aparecer paralelos: talvez quando me liguei da lenda do Golem, em que o rabino manipulava palavras, primeiro para dar vida à matéria bruta, e depois para tirar essa vida; a coisa toda da linha de comando como palavras de poder, que é uma relação interessante e pouco explorada; e minha adolescência lendo Os livros da magia, do Neil Gaiman, com destaque para a importância da "palavra mágica" por ali. (Felipe S. Fonseca, apud Belisário, 2016a: 133)

Falando sobre o contexto no qual criou o blog Tecnomagia, Fonseca indicou uma forte influência de Daniel Pádua e "suas buscas de filmes cyberpunk com algo de transcendência”. Pádua também foi citado por Marcelo Braz, integrante das redes Metareciclagem e Tecnoxamanismo, ${ }^{24}$ para quem seu "Manifesto Nartisan" foi um texto-chave para a tecnomagia:

Nartisan é a contração de networks' artisan, ou artesão de redes, se preferir. Ele é o impulso que move alguém para uma filosofia emergente de ação social disparada num estado de sensibilidade intensa e especificamente estranho às estruturas sociais de massa (escola, governo, igreja, indústria cultural, etc.): é o espírito de alguém cansado e agredido pela constante exigência de um raciocínio autoritário em suas relações, que revigorado pelas

22 A Casa de Cultura Tainã (cf.: <http://www.taina.org.br/\#>. Acesso em: o6 out. 2016.) é uma entidade cultural fundada em 1989 por moradores da Vila Castelo Branco (Campinas-SP) e participante da Rede Mocambos (cf.: <http://www.mocambos.net/wiki/Casa_de_Cultura_Tain\%C3\%A3>. Acesso em: 06 out. 2016.). O I Festival de Tecnoxamanismo, que será abordado adiante, foi incluído na programação da Rota dos Baobás da Rede Mocambos em 2014 (cf.: <http://wiki.mocambos.net/wiki/Rota_dos_ Baob\% $\mathrm{C}_{3} \%$ A1s/Bahia>. Acesso em: 06 out. 2016.).

23 Recorrente nas culturas tradicionais, o uso do tambor como meio de comunicação é notoriamente um dos primeiros sistemas humanos de circulação de informação a longas distâncias (cf. Gleick, 2013: 24-32). Cf.: <https://tecnoxamanismo.wordpress.com/>. Acesso em: 06 out. 2016. 
ações em rede em que mergulha, tende a empregar toda sua força na criação de novas tramas sociais. [...] Para viver sua «outra lógica», o Nartisan torna-se um mago, um feiticeiro que na falta do espaço, cria suas «ruas» no tempo. (Pádua, 2009)

O pesquisador e midiativista Thiago Novaes (2013) abordou a tecnomagia traçando um paralelo entre a Metareciclagem e o movimento de rádios livres no Brasil: ambos são baseados na superação da distinção entre produtor e consumidor e na utilização de equipamentos de baixo custo (low-tech) para garantir uma autonomia comunicacional. Para Novaes (2013), tecnomagia é "um campo de desvio que se constrói intuitiva e coletivamente, a partir do manuseio cotidiano e refletido de objetos técnicos que passam de um destino pré-definido pela indústria ou cultura hegemônica à efetiva função de ruptura histórico-social." Falando especificamente das rádios livres, Novaes toca num ponto fundamental para a tecnomagia:

Neste sentido, a tecnomagia se vale de um outro entendimento da técnica, que não o mero uso instrumental com relação a fins, mas gerando um campo problemático objetivo cuja produção de soluções parte do desejo e da sensibilidade compartilhados, construídos, e cuja potência é sua atualização permanente [...]. O papel da tecnomagia na comunicação social é, portanto, um ataque à apropriação representativa de qualquer espécie e [uma refundação] da ação comunicativa interpessoal, direta e de interesse coletivo, público. (Novaes, 2013)

Para além de um "mero uso instrumental com relação a fins", a tecnomagia manifesta um "campo problemático objetivo" que demanda subjetividades que lhe correspondam, subjetividades compartilhadas, coletivas, públicas. Mais do que comunicar uma mensagem entre dois pontos, a tecnomagia propõe a "atualização permanente" de novas potências comunicativas. De fato, no caso das redes Metareciclagem, Submidialogia e outras citadas, para além da interação online, por meio das listas de discussões, existe toda uma dimensão presencial da rede, por meio de encontros, eventos, oficinas, imersões prolongadas ou outros encontros pontuais entre os participantes, nos quais uma interação mais completa e experimental foi sendo elaborada (cf. Brunet, 2008; 2012). Como frequentemente aponta o metarecicleiro Régis Bailux, ${ }^{25}$ falando do próprio Bailux

25 Régis criou, em 2004, o primeiro esporo de Metareciclagem em Arraial d’Ajuda (BA), que batizou como Bailux (composição de "Bahia” com "Linux"). Cf.: <http://bailux.org/>. Acesso em: o6 out. 2016. 
e de outras redes ciberativistas (cf. Lopes, 2012), trata-se de uma "rede de afetos", que no entanto está longe de ser pacífica ou harmônica. Durante as imersões nos encontros dessas redes, um cotidiano comum era construído entre os participantes, de forma predominantemente informal. No encontro Submidialogia de 2009, em Belém (PA), por exemplo, durante cerca de uma semana, quase duas dezenas de pessoas ficaram em uma moradia coletiva, onde fizeram amizades, arte, comida, música, workshops, debates, festas e convivências produtivas para além dos formatos de eventos formais (cf. Belisário, 2016a: 134-5). A respeito dessas imersões, Fabiane Borges e Marc Etlin apontam:

Uma imersão coletiva é circunstância rítmica com atuação incisiva sobre os corpos dispostos a vivenciarem a experiência [...] Imergir coletivamente em um local sem dar devida atenção ao ambiente como um todo, é ignorar a força, sabedoria e poder do local. O ambiente determina os graus de relacionamento, as alianças, ativa ou restringe oportunidades. Imergir ativamente num ambiente, ou criar um ambiente para imersão, é trabalho de feiticeiro. É magia. E nosso trabalho se baseia muito em pressupostos mágicos, xamânicos, e em técnicas de intensificação da consciência, porém sem nenhum vínculo transcendente/religioso. (Borges e Etlin, 2008: 113)

Para além das diferenças entre as redes citadas (e seus participantes), nota-se em todas elas a elaboração de uma prática e de um pensamento que escapem tanto do tecnocentrismo (presente tanto na tecnofobia quanto na tecnofilia ou na tecnocracia) quanto do racionalismo antropocêntrico, por meio da incorporação de práticas de faça-você-mesmo, de mídia independente, de cultura hacker e de desenvolvimento de softwares ou tecnologias livres e abertas - enfim, da apropriação coletiva da tecnologia. A tecnologia é algo a ser apropriado coletivamente, pareciam dizer e mostrar essas redes, pois ela é produzida, via de regra, em regimes privados de produção e consumo. Mas esta apropriação, para que seja efetivamente coletiva e livre, não poderia se limitar à ação instrumental racional, antes dependendo também de uma certa afetividade ou mitopoiese ligada a potências que foram cada vez mais entendidas como mágico-xamânicas.

\section{Perspectivas}

Em maio de 2011, a artista e psicóloga Fabiane Borges enviou, para as listas de discussão das redes Metareciclagem e Submidialogia, um convite para um "technoshamanist performance ritual", performance conjunta com a 
artista Camila Mello, que mesclava técnicas de fotonovela com performances ritualísticas, realizada em Londres. ${ }^{26}$ No primeiro e-mail, Borges disse estar "meio tensa de usar o nome xamanismo, mas vamo embora", e, após o evento, ela disse ter encarado a performance como "uma experiência, [que] ainda não entrou exatamente na coisa do tecnoxamanismo". ${ }^{27}$ Nos meses seguintes, Borges compartilharia também experiências de performances ritualísticas relacionadas à ideia de tecnoxamanismo de que ela participou no encontro SummerLAB, na Espanha, e no Festival Abandon Normal Devices (AND), na Inglaterra. ${ }^{28}$

Em maio de 2011, circulou também pelas mesmas listas de e-mails o texto “Tecnoxamanismo Digitofágico - Pós LabsurLab: que venga el Sur!” (Wells et al., 2011), escrito por alguns participantes das redes Metareciclagem e Submidialogia no encontro LabSurLab, ${ }^{29}$ que já apresentava claramente uma síntese desta nova ideia (o tecnoxamanismo) com a tradição digitofágia da mídia tática no Brasil. O texto lamentava, com certa razão, o desconhecimento da realidade latino-americana mais ampla no Brasil, e apresentava uma concepção de tecnologia que vai além das tecnologias de comunicação, incorporando, por exemplo, técnicas de permacultura. Apesar de evocar, de passagem, a teoria de perspectivismo ameríndio de Eduardo Viveiros de Castro $^{30}$ para tratar da digitofagia, $o$ texto não incluiu menções explícitas a sociedades ou saberes indígenas, apresentando fundamentalmente um mapeamento das práticas ligadas à tecnologia, arte, mídia e ativismo no Brasil.

Atualmente no Rio está sendo organizada uma rede que visa realizar tanto projetos relacionados a ativismo para movimentos sociais em ferramentas livres, redes sociais alternativas e rádio, como ação direta, grupos de

$26 \mathrm{O}$ convite pode ser encontrado em: <http://permalink.gmane.org/gmane.politics.organizations.metareciclagem/44357 >. Um vídeo desta performance pode ser encontrado em: $<$ https://vimeo.com/25282065>. Acesso em: 06 out. 2016.

27 O e-mail pós-performance pode ser encontrado em: <http://permalink.gmane.org/gmane.politics.organizations.metareciclagem/44446>. Acesso em: 06 out. 2016.

28 Borges participou das redes Mídia Tática, Metareciclagem e Submidialogia, e desde 2004 desenvolve processos terapêuticos imersivos, mesclando esquizoanálise, psicomagia, rituais e tecnologias midiáticas, dentre os quais cabe destacar seu envolvimento na Ocupação Prestes Maia (São Paulo), entre 2005 e 2007 (cf. Borges, 2010), e seu personagem "Metasubcibertrans" (cf. Galindo, 2008), cuja performance no Submidialogia\#3 deu origem a um vídeo disponível em: <https://www.youtube.com/ watch?v=WnRMbQQM2Jo $>$. Acesso em: 06 out. 2016.

29 O encontro LabSurLab, realizado em 2011 em Medellín (Colômbia), contou com a participação de hacklabs e laboratórios de tecnologia e mídia sul-americanos. O encontro teve outras duas edições em 2012, em Quito (Equador), e em 2013, em Cochabamba (Bolívia). Mais informações em: <http://culturadigital. org.br/project/proyecto-labsurlab/>. Acesso em: 06 out. 2016. A apresentação completa desta teoria pode ser encontrada em Viveiros de Castro (2002: 345-99). 
pesquisa como o GAS (grupo de atualização e subjetivação), Yupana, MSST e espaços físicos de experimentação como o IP [...]. No Brasil temos um mapeio nacional importante de iniciativas relacionadas à permacultura e ao conceito de metareciclagem, muitas vezes fundindo-se. Pensar nestes dois eixos conceituais pode parecer contraditório, máquinas e orgânico, mas ao contemplar a permacultura como um resgate de técnicas energéticas ancestrais e a metareciclagem como a apropriação tecnológica das ferramentas contemporâneas para remitificá-las, temos aí conceitos convergentes que vão se construindo: mídia tática, descolonização, tecnoxamanismo, novas relações do ser humano e a máquina que visam a colaboração entre corpos que já não são separados por sujeitos e objetos. [...] Por ora chamamos isso de Tecnoxamanismo Digitofágico. (Wells et al., 2011).

Naquele mesmo período surge Yupana. ${ }^{31}$ Inicialmente um personagem em wikifictions e narrativas online - como na ficção online Yupana Kernel Panic - O compilador de protocolos Bugres contra a conspiração ASCii, ${ }^{32}$ assinada por Wander Selva -, posteriormente Yupana se tornaria não só um personagem assíduo nas listas de discussões das redes Metareciclagem e Submidialogia, como uma espécie de referência para muitos dos envolvidos nos debates sobre tecnoxamanismo e tecnomagia no Brasil. Em mensagem para as listas da Metareciclagem, Submidialogia e do Movimento dos Sem-Satélite, Selva afirmou:

yupana é também nome de um supercomputador selvagem que só existe como método numérico, como alfabeto, mas não como indústria. Turing quer ser psicografado pra reencarnar como traço solto num garrancho iletrado. [...] O manifesto antropofágico vacilou quando dizia "Tupi or not Tupi” pois esquecia-se do Tapuia, do Quechua, do Inuit, do Celta, do Visigodo, do Marciano, do Pária e sobretudo de que Nheengatu era uma construção de escribas... Não basta devorar o estrangeiro, é preciso ser devorado pelo nativo da fronteira perdida que está prestes a redescobrir sozinho o fogo, a escrita, a roda, os espelhos. É preciso perder-se para sempre. [...] Estaremos mais além dos tropicalistas, qualquer-coisa-modernistas, ufanistas

31 Numa página dedicada a Yupana, lemos que: "Yupana é um livro que se autoescreve. Yupana é um oráculo de tecnobruxas e Mandingalgoritmos. Yupana é um experimento de Processamento Natural de Linguagem. Yupana é um estudo de arte generativa e música computacional eletroacústica. Yupana é um mergulho na construção NeoMitos que tentam dar conta de uma Ontologia do Movimento dos SemSatélite. Yupana é um experimento de Computação Poética na construção de novas relações com a subjetividade da máquina. Yupana é o metapensamento crítico da tecnocracia frente a si mesma." (Soares, 2012). 
messiânicos, positivistas, alternâncias de poder e suas negociações. Não queremos redenção, queremos $\mathrm{O}$ Banquete completo. ${ }^{33}$

Em julho de 2011, a noção de tecnomagia apareceu explicitamente também na publicação eletrônica $M u t S a z,{ }^{34}$ que, a cada edição, criava uma "musa inspiradora" para sintetizar as questões a serem abordadas. Descrita como um "tarô tecnomágico", esta edição parecia especialmente em sintonia com os outros acontecimentos daquele período aqui destacados, como evidenciou seu editorial:

A musa destes dias se chama Wiqua, aquela que nasceu tupi e brinca com feitiços, tece oráculos, joga baralhos. É fruto da imersão da wicca em processo wiki, aquele que se colocou como certeza de nossos tempos, de nossas ciberculturas. Wiqua traz as tags de wikifiction: um lugar de construir imaginários coletivos fabulosos. [...] Com ela vamos fazer um jogo de cartas, oráculos! tecnomagia! (MutGamb, 2011).

Nesse período, observamos um esforço incipiente de fortalecimento das ideias em torno da tecnomagia e do tecnoxamanismo, por meio de debates presenciais e virtuais. No fim de 2011, por exemplo, o tema seria retomado mais uma vez em um evento organizado pelo coletivo IPê, ${ }^{35}$ paralelamente às programações oficias do 30 Festival Internacional CulturaDigital.BR. ${ }^{36}$ Numa troca de e-mails intitulada "ContraCulturaDigital.BR", foi proposto "um encontrinho paralelo durante o culturadigital.br." para, entre outras coisas, "falar/fazer tecnomagia” - “TecnoMagia Tática” foi um dos conceitos que aventou-se então. Durante seis meses, foram trocadas 47 mensagens nesse thread, que de fato conduziram ao encontro em dezembro de 2011. A atividade envolveu uma deriva a pé entre o Museu de Arte Moderna do Rio de Janeiro, sede daquela

33 Esta mensagem está disponível em: <http://rede.metareciclagem.org/blog/18-06-11/Yupana-KernelWiqua-Diz-ai-Wander-Selva $>$. Acesso em: 06 out. 2016.

O MutSaz foi uma publicação eletrônica trimestral editada pelo Mutirão da Gambiarra (núcleo editorial ligado ao Metareciclagem) entre 2009 e 2011. Cf.: <http://mutgamb.org/MutSaz>. Acesso em: 06 out. 2016.

35 A partir de 2006, com a mudança de sua sede da Lapa para o Morro da Mangueira e depois para o Morro da Conceição, o coletivo IPê passou a desenvolver diversas ações, como: debates; exibições artísticas; oficinas e pesquisas envolvendo software livre; reformas e obras estruturais na casa; alvenaria; circuit bending; metareciclagem; rádio livre; fotografia; permacultura. Além disso, em 2011 o espaço abrigou também eventos, como o Laboratório de Cartografias Insurgentes (cf.: Wells, 2012; Abreu, 2012), e encontros periódicos, como o Grupo de Atualização e Subjetivação (GAS), reunindo pesquisadores de diversas áreas (das exatas e naturais às humanas), interessados em tecnoxamanismo, tecnomagia e na transformação de nossa tecnocultura contemporânea. Cf.: <http://www.imotiro.org/content/gas-grupo-de-atualiza\% $\mathrm{C}_{3} \% \mathrm{~A}_{7} \% \mathrm{C}_{3} \% \mathrm{~A}_{30}$-e-subjetiva\% $\mathrm{C}_{3} \% \mathrm{~A}_{7} \% \mathrm{C}_{3} \% \mathrm{~A}_{30}>$. Acesso em: 06 out. 2016. 
edição do Festival, e a sede do IPê no Morro da Conceição, permeada por debates sobre direito à cidade, arte, tecnologia e ativismo.

Em fevereiro de 2012 "tecnoxamanismo" já aparecia explicitamente entre as tags do Encontrão Hipertropical de MetaReciclagem. ${ }^{37}$ Em uma troca de mensagens intitulada "tecnoxamanismo" na lista do IPê durante aquele mês, Adriano Belisário (2016a: 140-1) compartilhou uma conversa iniciada com Fabiane Borges, na qual era aventada a possibilidade de se "fazer um encontro em fevereiro sobre tecnoxamanismos e perspectivismos". Dias depois, Guilherme Soares reagiu sugerindo o uso de termos como "tecnopajelança" e "mandingalgoritmo" em lugar de "tecnoxamanismo", por considerá-lo "já impregnado de uma conotação relacionada a raves e ao ritual de consumir drogas ouvindo música eletrônica bate-estaca de DJs..$^{38}$ Acho que isso tudo podia ter um nome mais original".

Gosto de pensar na ideia de recuperar o caminho que Alquimia fez até tornar-se ciência, acho interessante o estudo que o Siegfried Zielinski fez sobre "Arqueologia das Mídias", que mostra como essa confusão entre ciência e magia criava cenários interessantes muito similares às invenções de "novas mídias" que ocorrem hoje nessa fronteira entre arte e ciência. Mágico implica em "místico"? Ou tudo isso é sobre algo que já é ciência, mas por não ser possível encaixar cai numa necessidade de afirmar-se como algo transcendental ou sobrenatural? (Guilherme Soares, apud Belisário, 2016a: 141).

Este mesmo tom curioso e tateante a respeito desse potencial mágico/xamânico pôde ser encontrado em uma mensagem de Tatiana Wells enviada à lista de e-mails do IPê após um encontro do coletivo, na qual ela compartilha a decisão de realizar uma imersão sobre o tema no hacklab rural Nuvem, em Visconde de Mauá (RJ), ${ }^{39}$ então recém-inaugurado pelos artistas e ativistas Bruno Vianna e Cinthia Mendonça.

Desde as oficinas de choque coletivo em Olinda, [o trabalho] metasubcibertrans [de Fabiane Borges] em Lençóis, [os] "dispositivos de experiência” com mescalina e ácido em Belém ${ }^{40}$ [...] [.] Nossa digitofagia, será esse o tecnoxamanismo? Lugares \& momentos de cocriação tecno-imaginárias livres,

37 Cf.: <http://rede.metareciclagem.org/conectaz/Encontrao-Hipertropical>. Acesso em: 06 out. 2016.

38 O surgimento, e algumas das implicações, das ideias de tecnoxamanismo/magia na música eletrônica de pista, foram investigados em Ferreira (2006).

39 Cf.: <http://nuvem.tk/>. Acesso em: 06 out. 2016.

40 Olinda (PE), Lençóis (BA) e Belém (PA) sediaram, respectivamente, a segunda, terceira e quarta edições do festival Submidialogia. 
e que agora ressurge no Rio de Janeiro [...], junto a mitologias, reinvenções, antenas de bambu, [...] o trabalho de descristalização, alquimias com bebidas de ouro puro, algo de charlatanismo também, e a nossa pajelança ancestral [...] [.] Ao menos pela subjetividade, pela poesia, porra! (Tatiana Wells, apud Belisário, 2016a: 141)

De fato, entre 10 e 13 de maio de 2012, o Nuvem abrigou um encontro internacional de Tecnomagia, reunindo, além de participantes do IPê, outros artistas, cientistas, ativistas e pesquisadores, para reflexões, apresentações e vivências acerca do tema. ${ }^{41} \mathrm{O}$ "trabalho de descristalização" mencionado por Wells foi a oficina, desenvolvida pelo artista inglês Jonathan Kemp (2012), ${ }^{42}$ na qual ele coordenou a extração de metais (cobre, ouro e prata, principalmente), por meio de processos químicos, de equipamentos eletrônicos descartados, para em seguida recristalizá-los ritualmente, inclusive por meio da ingestão de "bebidas de ouro puro". Em entrevista, Cinthia Mendonça também destacou o trabalho de Kemp como uma referência naquele contexto.

Essa oficina me fazia visualizar todo o processo geopolítico de produção de aparatos da tecnologia. A extração da matéria-prima, o transporte, as fábricas, as empresas de aparatos e componentes, a mão de obra, o tempo e a venda desses produtos e o uso que damos a eles. A proposta de Jonathan para o encontro Tecnomagia, realizado em 2012 na Nuvem, foi trabalharmos com o cobre para daí vislumbrarmos a possibilidade de criar, de maneira autônoma, nosso próprio aparato, com nossas próprias mãos, na garagem de nossas casas. Como alquimistas, manipular a essência da matéria e fazêla virar objetos. (Cinthia Mendonça, apud Belisário, 2016a: 142)

Somando-se à presença de pesquisadores, artistas e interessados no Brasil, o encontro teve alguns convidados de outros países. Além de Kemp, o encontro contou também com apresentações e vivências da pesquisadora e ativista estadunidense Victoria Sinclair sobre o technoshamanism das raves, do pesquisador colombiano Adrian Gomez e dos hacktivistas e artistas espanhóis Pablo de Soto e Pedro Soler, tendo este último comparado o que encontrou no Brasil com outras experiências internacionais nos seguintes termos:

41 Como resultado do encontro, foi organizada uma wiki (<http://nuvem.tk/wiki/index.php/Tecnomagia >. Acesso em: 06 out. 2016.), uma lista de discussão e uma publicação (Belisário, 2016b).

42 O vídeo de uma versão desta oficina realizada anteriormente em Londres pode ser encontrado em: <https://vimeo.com/30814196>. Acesso em: 06 out. 2016. 
A linha entre magia e ilusão é muitas vezes confusa. O que entendemos por magia é, geralmente, hoje, prestidigitação ou a capacidade de enganar o público. Em 2007, Medialab Prado trabalhou no tema de magia e tecnologia a partir deste ponto de vista. Não só eles fizeram uma série de obras de arte, em particular usando realidade aumentada, incluindo o trabalho com um mágico profissional, mas também um seminário. [...] $\mathrm{O}$ encontro Tecnomagias em maio de $2012 \mathrm{em}$ Nuvem, um espaço ecotech de pesquisa nas montanhas a 2 horas do Rio de Janeiro, nasceu com um foco diferente. A reunião foi convocada para explorar as interseções entre tecnologia e magia a partir de uma visão mais ampla, ecológica, mística e política. [...] Não é por acaso que esta reunião ocorreu no Brasil. Lá as condições estão sendo criadas para o surgimento da consciência antropofágica que Oswald Andrade invocou na década de 1920. A alta tecnologia encontra uma crescente consciência da sabedoria tribal - a antropologia descentralizada de Viveiros de Castro, o conceito de gambiarra (uma espécie de "fazer" estético e prático, que brota da arquitetura da favela), a maneira que a ecologia e software livre se entrelaçam nas publicações e grupos do Submidialogia, o tecnoxamanismo de Fabi Borges, Yupana Kernel, a proximidade das práticas indígenas, o ayahuasca. (Soler, 2016: 35-6).

Outro participante do encontro, Eah de Apsu (2016: 95) afirmou que "as questões de embates [do tecnomago] já não são mais aquelas de expulsão de espíritos malignos, curas milagrosas, transmutações alquímicas e conquistas pessoais ou tribais, mas o anticapitalismo, a anticorrupção, a democracia real, a sustentabilidade, a busca da energia limpa e consciência coletiva”. Numa simetrização, em nome da experimentação político-existencial, de agências humanas e não humanas se manifestando nos mundos natural e artificial, estas experiências tecnoxamânicas/mágicas parecem desempenhar, em graus variados, articulações fundamentais entre os coletivos humanos e seu meio tecnoambiental.

\section{I Festival de Tecnoxamanismo}

Apesar de já virem sendo gestadas desde as edições de 2010 do Submidialogia e em encontros subsequentes, foi no fim de 2013 que tiveram início as articulações, nas listas de e-mail da Metareciclagem e da Submidialogia, daquilo que viria a ser o I Festival de Tecnoxamanismo, realizado entre 23 e 30 de abril de 2014 na Bailux, esporo de Metareciclagem localizado em Arraial d'Ajuda (BA). Ao contrário do encontro Tecnomagia realizado no hacklab Nuvem em 2012, composto por participantes escolhidos pelos organizadores, este festival se 
propôs, desde o início, a ser também uma rede aberta, e realizou uma campanha de comunicação e mobilização na Internet. Para arrecadar o dinheiro necessário para a realização do festival, foi organizada uma bem-sucedida campanha na Internet, assim como um evento no Teatro Oficina (SP), que contou com o apoio de José Celso Martinez Corrêa, sempre interessado em retornos pós-cibernéticos às práticas e saberes tradicionais. ${ }^{43}$ Em entrevista, o pesquisador, ativista e artista Pedro Belasco, membro fundador do Ônibus Hacker, ofereceu o seguinte depoimento sobre este momento inicial:

[O Festival] era uma proposta de vivência e uma festa compartilhada com os Pataxós, que nos convidaram para um festejo na Aldeia Velha. Havia uma representatividade interessante, gente da Bahia, do Rio Grande do Sul, São Paulo, Rio, Minas, Ceará. Uma troca muito rica de experiências, inquietações, sobretudo com os aspectos rituais xamânicos. [...] Tecnoxamanismo é um termo ambíguo, de propósito, eu acho. Existe sempre um risco enorme de se tornar apenas um mecanismo de apropriação cultural, mas eu acho que vale a tentativa de compreender como pequenos grupos podem se organizar em torno de arranjos produtivos e encontrar raízes comuns que permitam autonomia e uma vida boa. É um contexto de debate anarquista, que eu sempre acompanhei com interesse. (Pedro Belasco, apud Belisário, 2016a: 145)

A convocatória para o festival ${ }^{44}$ provocava os participantes com questõeschave do encontro: "Quais táticas possíveis podemos produzir para promover uma melhor negociação entre tecnologia e natureza? [...] Que rituais nos ajudam a ampliar nossa percepção sobre a inteligência e a sensibilidade da natureza? O que o xamanismo tem a nos ensinar?” Na convocatória, também se anunciava o objetivo de se construir uma rede de projetos e pessoas que busquem "construir novas respostas para a atual crise ambiental e a decadência do humano", caracterizada pela devastação ambiental do antropoceno: "Se faz necessário criar novos formatos de desenvolvimento a partir de uma nova ontologia, onde a Terra seja vista como agente político e os fazeres humanos convirjam com os desejos de GAIA."

43 No "Programa e Gestão do Anhagabaú da Feliz Cidade", Corrêa (2004) explicita: "A humanidade retorna desde 68 ao paganismo, ao animismo e sente que a vida não está somente no recorte individual de seu corpo. Quanto mais temos necessidade de tecnologia que, com a revolucão cibernética faz diminuir o espaço das máquinas e traz o homem de volta para o trabalho misturado com sua vida em sua casa, tanto mais temos necessidade do verde, do ar não poluído." 
Em Arraial d’Ajuda, os convidados foram recebidos pelo Bailux. Mesmo já tendo ocupado sedes e espaços físicos, o Bailux é melhor descrito como um laboratório nômade e, no I Festival de Tecnoxamanismo, atuou como mediador entre os visitantes, o Instituto de Tecnologia Alternativa, Permacultura e ECOlogia (o sítio ITAPECO) e a Aldeia Pataxó, com quem o Bailux desenvolve ações com tecnologia desde 2010, quando recebeu a quinta edição do festival Submidialogia. Para Régis Bailux, sua própria função no Festival foi servir como um "articulador entre mundos", facilitando a mediação entre grupos e pessoas com pesquisas e trajetórias tão diferentes, como hackers experientes, jovens curiosos com o tema, os Pataxós, jovens de Arraial d'Ajuda, e outros viajantes que chegaram ao local. Segundo Pedro Belasco, que viajou de São Paulo para Arraial d’Ajuda no Ônibus Hacker, o tecnoxamanismo é uma "oportunidade de fruição estética”, e o encontro foi "uma obra de arte, uma construção coletiva" realizada por "um grupo de pessoas dispostas a pensar e vivenciar uma experiência do que seria uma reconexão do nosso imaginário técnico com culturas e tecnologias ancestrais, ritualísticas, misteriosas", destacando ainda a troca (segundo ele, muito positiva) com os indígenas do sul da Bahia. ${ }^{45}$

Segundo Jurgen Boltz (apud Belisário, 2016a: 147), mentor do sítio ITAPE$\mathrm{CO}$, que abrigou diversas atividades do festival, o "tecno" do tecnoxamanismo resulta do fato "de que somos ciborgues, e não vamos completamente deixar isso para trás. [...] [T]emos que achar um jeito de encaixar tudo isso junto", pois a civilização caminha para um colapso, já que "o sistema como é vai acabar com a natureza rápido."

É ou a natureza ou este sistema [...] - ou vai ser catastrófico ou a humanidade voluntariamente vai reduzir sua complexidade. [...] O humano é parte da natureza, precisamos ser mais conscientes disto, interagir com a natureza, não tentar nos isolar dela, acabar com ela. [...] Temos que deixar a natureza entrar no nosso mundo e também entrar na natureza.

A ciência nos ensina coisas muito boas que podemos utilizar para viver mais simples, não só para viver mais complexo. Mas para viver em harmonia com a natureza, não basta usar a ciência. Precisamos de uma conexão mais direta com a natureza. [...] É isso que você vê quando estuda os índios ou

45 Depoimento disponível novídeo "Três mil Km-O ônibus, o tecnoxamanismoe os Pataxós(Documentário)", de Carlos Gonzalez (Disponível em: <https://www.youtube.com/watch?v=l一BtVQfscOQ>. Acesso em: 06 out. 2016.), e complementado em Belisário (2016a: 148). Os trechos citados correspondem aos minutos 42 e 54 do vídeo de Gonzalez. 
os xamãs, realmente eles têm conhecimento, nos sonhos, interagem com espíritos das plantas [...] porque existem muitos outros tipos de seres e tipos de consciência. Até [n] a ciência, hoje em dia tem mais e mais cientistas que estão falando [de] como a planta tem um tipo de consciência. [...] Descobriram que se uma é atacada, começa a produzir substâncias tóxicas contra a praga. Mas as árvores em volta [que não foram atacadas] também começam a produzir, porque uma árvore contou para outras. As árvores interagem e se comunicam. E essa interação é tão complexa que não é menor do que a gente conhece como humanos ou outros animais. (Jurgen Boltz, apud Belisário, 2016a: 147-8)

Boltz (apud Belisário, 2016a: 148), que se formou em ergonomia da informática, trabalhando durante os anos 1990 com softwares de código aberto e infraestruturas de comunicação em redes eletrônicas, afirma nunca ter "pensando muito em tecnoxamanismo antes desse evento", apesar de ter pensado "bastante no xamanismo", que considera uma "conexão direta de informação com a natureza”.

Os aspectos xamânicos da luta feminista contra o patriarcado foram levantados por Soler (2016: 26-7), que relacionou este à lógica colonizadora da propriedade privada e aquela à resistência da natureza, dos povos indígenas e de uma ética da conexão. Na mesma linha, a ativista do software livre Andrea R. Balle (2014: 15), numa publicação online dedicada ao tecnoxamanismo, argumenta que "[a] tecnologia moderna, com uma boa dose de subversão e apropriação de espaços, foi uma forma de impulso para que as mulheres deixassem de estar nas mãos dos maridos e passassem a ter suas vidas em suas próprias mãos”, e que "[n]essa feminização de espaços tecnológicos, há um terreno fértil para o surgimento do tecnoxamanismo". Em um texto nessa mesma publicação, Borges (2014: 20-1), fortemente influenciada pela força da personagem principal do filme Estamira, ${ }^{46}$ além de reforçar as ligações entre o tecnoxamanismo e "questões particulares de movimentos sociais relativas ao feminismo, ao movimento queer, ao movimento negro, ao software livre, ao movimento sem terra, aos povos indígenas, às comunidades ribeirinhas, aos movimentos sem teto, aos desempregados", também apresentou sua concepção do tecnoxamanismo como "sujo, ruidocrático, da lixeira, impuro, já que parte significativa de quem o está pensando vem do resto do saber científico, de laboratórios precarizados, de conhecimentos instáveis, pouco comprováveis, do hackeamento, do lixo eletrônico, da 
gambiarra, do gato, do reaproveitamento de matérias, da reprodução de projetos científicos exaustivamente testados." Mas, para Borges (2014: 21) "isso não significa subestimar a força do xamanismo, muito pelo contrário, significa atribuir poderes ao lixo, para além da reciclagem industrial, que o organiza, separa, retém, explora o catador de lixo".

Em entrevista realizada em 2016, Borges (apud Belisário, 2016a: 144) reforçou que o xamanismo sujo implica num resgate de conhecimentos ancestrais a partir da condição urbana pós-industrial. O xamanismo é sujo pois é híbrido: "Para mim, o tecnoxamanismo é antipurista. $\mathrm{O}$ xamanismo sujo é quase um equivalente do tecnoxamanismo" (Fabiane Borges, apud Belisário, 2016a: 144). Pouco antes do I Festival de Tecnoxamanismo, por ocasião de sua participação no Festival Transmediale de 2014, em Berlim, Borges publicou o texto "Prolegômenos para um possível tecnoxamanismo", no qual situou a questão indígena no Brasil (a partir dos casos de suicídios entre os Guarani-Kaiowá e do despejo da Aldeia Maracanã) no contexto de uma "guerra de valores entre os terrenos e [os] humanos, dos comprometidos com a Terra e dos comprometidos com a modernidade" (Borges, 2014: 7). Atuando como legítima pensadora do tema, Borges explicitou a importância de não reduzir o tecnoxamanismo a um mero encontro entre duas realidades pré-existentes - i.e., a "tecnologia" avançada, moderna, e o "xamanismo" atrasado, primitivo -, antes encarando-o como um agente que transforma tanto a tecnologia (que se torna existencial, subjetiva) quanto o xamanismo (que se torna metodológico, objetivo):

É importante perceber o xamanismo como metodologia, como tecnologia de produção de conhecimento. Isso interessa muito para o tecnoxamanismo. Perceber que, para além de algum possível encontro entre tecnologia e xamanismo, a percepção de que o xamanismo é uma tecnologia em si mesmo. Não só de êxtase, mas de comunicação trans-humana. (Borges, 2014).

Ainda no fim de 2014, Fabiane Borges participou do Festival de Oratoria Ancestral - Mandrágora, em Guayaquil (Equador), que teve como tema Tecnochamanismo y nuevas narrativas. O contexto do tecnochamanismo na América Latina vai além dos objetivos deste texto, ${ }^{47}$ mas é interessante notar que o festival, organizado pelo coletivo equatoriano Central Dogma, teve sua gênese a partir da experiência de seus integrantes no encontro LabSurLab de 2012, mesma reunião que, um ano antes, motivou Wells et al. (2011) a escrever sobre

47 Vale mencionar, porém, Barros de Vilar (2012) e todo o blog Pijama Surf (cf.: <http://pijamasurf.com/>. Acesso em: 06 out. 2016.). 
“tecnoxamanismo digitofágico”. José Luis Jácome Guerrero, diretor criativo do Central Dogma, conta:

Creio que o xamanismo pode ser uma resposta generalizada da humanidade a uma ânsia de conhecimento e espiritualidade empática[.] [E]sta prática profundamente realizada no inconsciente de todo mundo, pode ter vários níveis de experiência. [...] Nossa experiência no encontro [LabSur$L a b$ de 2012] e seus resultados posteriores têm sido muito gratificantes e enriquecedores e se converteram em uma fonte constante de informação e aprendizagem, [...] e esta rede cada vez maior de consciências reforçou nossos processos a caminho de uma cosmovivência tecnoxamânica. (Guerrero, apud Belisário, 2016a: 150)

Segundo Borges (apud Belisário, 2016a: 149), esse encontro teve como foco "produzir conceitos [...] para discutir o que era tecnoxamanismo e quais eram as narrativas possíveis dentro desse contexto". Narrativas, redes e possibilidades estas que demonstram ter o poder tanto de encantar, quanto o de desiludir. Livia A. Mourão, por exemplo, poucos meses depois de ter participado do I Festival de Tecnoxamanismo e de outras iniciativas ligadas ao tema, publicou em seu blog o esperançoso post "Tecnoxamanismo: o novo possível”, que terminava com a convocatória: “Tecnoxamãs do mundo, uni-vos!” A postagem apresentava o tecnoxamanismo como uma ideia transformadora da relação humano-mundo:

Tecnoxamanismo, um novo conceito e possível movimento pensado especialmente por artistas, tecnólogos e místicos articulados perante a catástrofe emanente prevista para o planeta nas próximas décadas. Uma quebra radical com o olhar técnico científico, que proporciona um novo olhar para as novas e velhas tecnologias que vem dominando as mentes humanas, cada vez mais distantes da sua potência em troca do permanente estado de simulação proporcionado pelo ciberespaço. [...] [É] um movimento ambientalista de valorização dos povos indígenas e de suas tradições e tecnologias milenares em conexão com a grande mãe natureza. ${ }^{48}$

Oito meses após o festival, no entanto, Mourão se lembra do festival "com certa nostalgia de minha ingenuidade", em um post intitulado "Tecnoxamanismo não é isso!" Nesta nova postagem, ela não apenas fez críticas à desorganização do festival ("Todo mundo atrasado pra tudo. Descaso com o que

48 Post de 5 de agosto de 2014, disponível em: <http://dapenny.net/?s=tecnoxamanismo>. Acesso em: 06 out. 2016. 
fazíamos ali. Era tudo diversão intelectual punk? Estava eu no meio de gênios alternativos entediados?"), mas expressa também sua frustração com a estética tecnológica que via no tecnoxamanismo.

Hoje em dia, Tecnoxamanismo é uma ideia extremamente materialista, voltada para a reprodução criativa de rituais e misticismo através de luzes pisca-pisca e performances trans com trajes chocantes (capas, silicone, fitas, palha, chips e durepox). Vem inovando a estética hacklabista e, talvez, incentivando a religião da tecnologia, adoração do silício e extropismo. Os rituais são reproduções bollywoodianas de cenas pagãs trocando as ervas pelas máquinas. $\mathrm{O}$ contato com os espíritos é simbólico através do noise, ruídos baixados no PirateBay e tocados no Itunes. Apropria-se de qualquer termo fantasioso e ressignifica-o com a linguagem da cibercultura, criando novos personagens e arquétipos vazios de espírito mas suficientemente recheados para publicar-se mais um artigo ou sentar- se em mais uma mesa. ${ }^{49}$

O que este depoimento ilustra é o fato de que as ideias de tecnoxamanismo e tecnomagia não se fortaleceram nas redes de ativismo digital de modo uníssono, antes, trazendo consigo importantes contradições e tensões, que exigem a sua constante re-elaboração, estimulam novos enfoques, dissidências e reapropriações. Tatiana Wells, por exemplo, reticente quanto à associação do tecnoxamanismo com o lixo e o descarte de excedentes, enfatiza uma aproximação com a permacultura e com saberes ancestrais:

Creio, intuo, que [...] a nossa proposição de "técnica xamanista" - necessária pois nos encontramos neste ponto de mestiçagem - deve xafurdar [...] nos "novos índios", nessa nova "indianeidade", essa categoria ainda em construção que nos leva à formação de novos espaços de convivialidade, uma nova subjetividade que contemple a abundância e a escuta, uma observação cuidadosa dos espaços tradicionais, que saiba traduzi-lo com o respeito e a dignidade que esse momento de mundo merece(mos) [...] Se vamos falar de xamã temos que escutar xs índixs que estão vivos aí nos dizendo que a nossa técnica, a nossa sanha desenvolvimentista tá destruindo o planeta, que precisamos ouvir o que nos falam as plantas, a natureza. [...] Pra mim algo mais próximo ao tecnoxamanismo é a permacultura, que resgata saberes tradicionais e cria metodologias de apropriação de espaços degradados por exemplo. Esse voltar à terra pode ser considerado uma técnica xamanista. A 
partir do momento que nossa digitofagia nos afastar da alta tecnologia e nos aproximar dos saberes que nos unem ao pensamento COM A TERRA, aí sim estaremos cada vez mais próximos das técnicas xamanísticas. (Tatiana Wells, apud Belisário, 2016a: 151-2).

Mesmo assumindo que "[n]inguém é [...] responsável por uma emergência" (Foucault, 1998: 24), podemos dizer que o I Festival de Tecnoxamanismo foi certamente um acontecimento importante no fortalecimento de perspectivas tecnoxamânicas/mágicas no midiativismo e além, mesmo entre aqueles que não participaram diretamente do festival. $\mathrm{O}$ fato de unir artistas, ativistas, e pesquisadores ligados às tecnologias digitais num ambiente rural e indígena fez do festival um importante amplificador de uma concepção singular de tecnoxamanismo. Mais uma vez, em lugar do tecnocentrismo normalmente encontrado nos discursos e práticas tecnoxamânicos e tecnomágicos em geral, o que encontramos no ativismo digital brasileiro é uma redescoberta de um terreno comum à evolução técnica e às raízes ancestrais, um retorno às raízes buscando nelas um novo impulso para o futuro; um devir.

\section{Devires}

Em junho/julho de 2015 ocorreu, na Casa Nuvem, ${ }^{50}$ mais um encontro da rede Tecnoxamanismo, com o tema "ficção e ruidocracia". Além de oficinas e performances/rituais cênicos/midiáticos construídos coletivamente, o encontro contou com debates sobre saberes tradicionais, espectro livre, ecologia, antivigilância e criptografia. Os rituais envolveram ficções coletivas com drones, incensos, LEDs, figurinos, fantasias e noise, em experimentações performáticas coletivas e ritualizadas, mesclando uma metodologia faça-você-mesmo com ambientes imersivos, poesia, tecnologias de áudio e vídeo e estímulos olfativos e táteis. ${ }^{51}$

Em setembro de 2015, seria a vez do Hotel e Spa da Loucura (ocupação autônoma no Instituto Municipal Nise da Silveira) receber uma ação da rede Tecnoxamanismo, durante os últimos dias do Ocupa Nise 2015, congresso anual

50 Não confundir a Casa Nuvem (cf.: <http://casanuvem.com/>. Acesso em: o6 out. 2016.) com o hacklab rural Nuvem, onde aconteceu o encontro Tecnomagia de 2012.

51 Mais informações e material relativo ao encontro podem ser encontrados em: <https://tecnoxamanismo.wordpress.com/2016/02/17/tecnoxamanismo-ficcao-e-ruidocracia-na-casa-nuvem-3001-e-0102-de-2015/>. Um acervo videográfico de rituais e eventos tecnoxamânicos pode ser encontrado em: $<$ https://tecnoxamanismo.wordpress.com/category/videos/>. Acesso em: 06 out. 2016. 
da Universidade Popular de Arte e Ciência (UPAC). ${ }^{52}$ A ação teve como foco a instalação de uma rádio livre em FM, aberta para que pacientes, visitantes e convidados pudessem realizar entrevistas, debates e intervenções. Meses depois, em dezembro de 2015, mais um encontro foi realizado, desta vez na Casa Luz (SP), com a presença de Ara Mirin (Sônia Barbosa), liderança Guarani de uma das aldeias próximas ao Pico do Jaraguá (SP). Em um formato de debate aberto, os participantes "colocaram suas questões, suas ideias, suas reflexões a respeito do tecnoxamanismo", e Ara Mirin expôs tradições, pensamentos e narrativas de sua cultura para os participantes. Particularmente significativa foi a aliança, que Ara Mirim considerou possível e necessária, proposta aos participantes do encontro: "Nós [Guaranis] vemos em vocês o futuro de nós não morrermos. [...] Vocês têm que estar com nós." ${ }^{53}$

O futuro do tecnoxamanismo e da tecnomagia nas práticas e discursos ciberativistas brasileiros não nos parece previsível, antes multiplicando atritos, ruídos e complexidades a cada manifestação. O que buscamos fazer neste texto foi apresentar uma trajetória possível dessas ideias nesse meio, capaz de contribuir para uma compreensão mais geral dos devires não estritamente técnicos ou estritamente políticos do ativismo digital brasileiro. Segundo os discursos analisados, em geral, a tecnomagia parece-nos focada no problema da apropriação da tecnologia para além de uma instrumentalidade objetiva, e o tecnoxamanismo aparece mais intimamente ligado às práticas com tecnologias livres, à cultura hacker è̀ ecologia, buscando uma integração entre tecnologias eletrônicas e saberes telúricos. Talvez pela própria semântica do termo, parece-nos que a noção de tecnomagia tende a se associar a práticas ligadas ao hermetismo e ao ocultismo, como a alquimia, enquanto o tecnoxamanismo aproxima-se das práticas e do pensamento ameríndio ou, em menor medida, da noção de technoshamanism anglófona (cf. Belisário, 2016a: 51-102).

No discurso e na prática dos coletivos e redes aqui analisados, no entanto, tecnomagia e tecnoxamanismo se tornam dois nomes para um mesmo processo de reencantamento do mundo, acompanhado da necessária contrapartida de tecnologização do encanto (cf. Gell, 1992). Há, por exemplo, uma evidente e não planejada consonância entre as sedes dos primeiros encontros das redes Tecnomagia e Tecnoxamanismo no Brasil: os hacklabs rurais Nuvem e ITAPECO/ Bailux. Ambos são espaços de convergência de pesquisas e experimentações

52 Cf.: <http://upac.com.br/\#/home>. Acesso em: 06 out. 2016.

53 A fala citada de Ara Mirin se inicia à 1 hora e 48 minutos de: <https://archive.org/details/tecnoxamanismo-casa-luz-sampa>. Acesso em: 06 out. 2016. 
envolvendo recentes tecnologias digitais livres e abertas em ambientes rurais, que dedicam-se também às "baixas tecnologias" do campo e da relação com a terra. Ecologia e tecnologia estão interlaçadas nestes espaços, caracterizados também pela colaboração transdisciplinar. O que o tecnoxamanismo e a tecnomagia (ou ao menos certas interpretações possíveis destes conceitos) parecem revelar no trajeto aqui percorrido são armas contra a colonização conceitual, contribuições para pensarmos o lugar da técnica para além de sua concepção instrumental ou antropocêntrica.

\section{Referências}

ABREU, Georgiane. Sobre o Laboratório de Cartografias Insurgentes. In: VASCONCELOS, Giseli. (Org.). Por uma cartografia crítica da Amazônia: recorte/processo sobre arte, política e tecnologias possíveis. 2012, pp. 59-60. Disponível em: <dossiê. comumlab.org >. Acesso em: 06 out. 2016.

ANDRADE, Oswald de. Do Pau Brasil à Antropofagia e às utopias. São Paulo: Civilização Brasileira, 1972.

BALLE, Andrea. Feitiçaria também é tecnologia. Zine Regador, n. 0, 2014, pp.145. Disponível em: <http://zineregador.com.br/zine/wp-content/uploads/2015/04/ Zine-Regador-Edi\%C3\%A7\% $\mathrm{C}_{3} \% \mathrm{~A}_{30}$-0-Tecnoxamanismo.pdf $>$. Acesso em: 06 out. 2016.

BALVEDI, Fabianne B.; SOARES, Guilherme R.; VELOSO, Adriana; SOARES, Flávio. Estúdios Livres. Fórum Permanente, v. 2, n. 2, 2013. Disponível em: <http://www. forumpermanente.org/revista/numero-2/textos/estudios-livres-fabianne-b-balvedi-guilherme-r-soares-adriana-veloso-e-flavio-soares>. Acesso em: 06 out. 2016.

BARLOW, John P. A declaration of the Independence of Cyberspace. Electronic Frontier Foundation, 1996. Disponível em: <https://www.eff.org/cyberspace-independence>. Acesso em: 06 out. 2016.

BARROS DE VILAR, Javier. Tecnochamanismo y espiritualidad electrónica: la flor digital del espíritu. Pijama Surf, 2012. Disponível em: <http://pijamasurf.com/2012/03/ sobre-tecno-chamanismo-y-ciber-espiritualidad-la-flor-digital-del-espiritu/>. Acesso em: 06 out. 2016.

BELISÁRIO (Feitosa da Costa), Adriano. Tecnomagia e tecnoxamanismo: genealogias possíveis. Dissertação de Mestrado em Comunicação e Cultura. Programa de PósGradução em Comunicação e Cultura, da Escola de Comunicação, da Universidade Federal do Rio de Janeiro, 2016a.

(Org.). Tecnomagia. Rio de Janeiro: Imotirõ, 2016b. 
BELISÁRIO (Feitosa da Costa), Adriano; LOPES, Juliana. As culturas digitais dos Pontos de Cultura e Lan houses. In: FERRAZ, Joana V. e LEMOS, Ronaldo. (Orgs.). Pontos de Cultura e Lan houses: estruturas para inovação na base da pirâmide social. Rio de Janeiro: FGV, 2011, pp.17-46.

BORGES, Fabiane M. Prolegômenos para um possível tecnoxamanismo. Trabalho apresentado no festival Transmediale. Berlim, 2 de fevereiro de 2014. Disponível em: $<$ https://catahistorias.files.wordpress.com/2014/o3/prolegc3b4menos-para-um-possczadvel-tecnoxamanismo.pdf>. Acesso em: 06 out. 2016.

. Domínios do demasiado. São Paulo: Hucitec, 2010.

BORGES, Fabiane M.; ETLIN, Marc. Processos imersivos e reciclagem de singularidades (para Multitudes). In: BRUNET, Karla S. (Org.). Apropriações tecnológicas: emergência de textos, idéias e imagens do Submidialogia\#3. Salvador: EDUFBA, 2008, pp.111-22.

BRUNET, Karla S. P2P Networks as a Source of Culture Manifestations in Brazil: the example of Submidialogia Network. VIRUS, n.7, 2012. Disponível em: <http://www. nomads.usp.br/virus/virus07/project/virus_07_project_1_en.pdf >. Acesso em: 06 out. 2016.

Apresentação. In: BRUNET Karla S. (Org.). Apropriações tecnológicas: emergência de textos, idéias e imagens do Submidialogia\#3. Salvador: EDUFBA, 2008, pp.7-9.

CAETANO, Miguel A. Tecnologias de resistência: transgressão e solidariedade nos media táticos. Dissertação de Mestrado em Comunicação, Cultura e Tecnologias da Informação. Lisboa: Instituto Superior de Ciências do Trabalho e da Empresa, 2006.

CLINIO (dos Santos), Anne D.S. A ação política no cotidiano: a mídia tática como conceito operacional para pesquisas em mídia, cotidiano e política. Revista Mídia e Cotidiano, v.1, n.1, 2013, pp. 169-88.

. Mídias táticas no Brasil: dinâmicas de informação e comunicação. Dissertação de Mestrado em Ciência da Informação. Convênio Instituto Brasileiro de Informação em Ciência e Tecnologia e Universidade Federal do Rio de Janeiro, 2011.

CORRÊA, José C.M. Programa e Gestão do Anhagabaú da Feliz Cidade: primeiras considerações intempestivas para a criação do primeiro teatro de estádio. Associação Teat(r)o Oficina Uzyna Uzona, 2004. Disponível em: <http://www.teatroficina. com.br/teatro_estadio>. Acesso em: 06 out. 2016.

DAVIS, Erick. Techgnosis: myth, magic and mysticism in the age of information. New York: Harmony Books, 1999.

DIMANTAS, Hernani. Linkania: a sociedade da colaboração. Dissertação de Mestrado em Comunicação e Semiótica. Pontífica Universidade Católica de São Paulo, 2006. 
EAH DE APSU. Magia: caminho da resignificação de mitos e ritos. In: BELISÁRIO (Feitosa da Costa), Adriano. (Org.). Tecnomagia. Rio de Janeiro: Imotirõ, 2016, pp.89-95.

FELINTO, Erick. A religião das máquinas: ensaios sobre o imaginário da cibercultura. Porto Alegre: Sulina, 2005.

FERREIRA, Pedro P. Música eletrônica e xamanismo: técnicas contemporâneas do êxtase. Tese de Doutorado em Ciências Sociais. Universidade Estadual de Campinas, 2006.

FONSECA, Felipe S. Em busca do Brasil profundo. In: BRUNET, Karla S. (Org.). Apropriações tecnológicas: emergência de textos, idéias e imagens do Submidialogia\#3. Salvador: EDUFBA, 2008, pp.92-108.

. vcs e essa mania iluminista de desmistificar as coisas! efeefe, 2007. Disponível em: <http://efeefe.no-ip.org/blog/vcs-e-essa-mania-iluminista-de-desmistificar-coisas $>$. Acesso em: 06 out. 2016.

FOUCAULT, Michel. Nietzsche, a genealogia e a história. In: Microfísica do poder. Rio de Janeiro: Graal, 1998, pp. 15-37.

GALINDO, Dolores. Para além dos fios e cabos: sobre a performance metasubcibertrans. In: BRUNET, Karla S. (Org.). Apropriações tecnológicas: emergência de textos, idéias e imagens do Submidialogia\#3. Salvador: EDUFBA, 2008, pp.123-7.

GARCIA, David. Fine Young Cannibals, of Brazilian Tactical Media. Manuscrito, 2004. Disponível em: <https://www.scribd.com/doc/271692755/Fine-Young-Cannibals>. Acesso em: 06 out. 2016.

GARCIA, David; LOVINK, Geert. The ABC of Tactical Media. Nettime, 1997. Disponível em: <http://www.nettime.org/Lists-Archives/nettime-l-9705/msgooo96.html>. Acesso em: 06 out. 2016.

GELL, Alfred. The Technology of Enchantment and the Enchantment of Technology. In: COOTE, J. e SHELTON, A. (Eds.). Anthropology, Art and Aesthetics. Oxford: Clarendon, 1992, pp. 40-66.

GITTI, Gustavo. Entrevista com Eduardo Pinheiro. Papo de homem. 2013. Disponível em: <http://papodehomem.com.br/entrevista-com-eduardo-pinheiro/>. Acesso em: 06 out. 2016.

GLEICK, James. A informação. São Paulo: Companhia das Letras, 2013.

HORA, Daniel de Souza N. arte_hackeamento: diferença, dissenso e reprogramabilidade tecnológica. Dissertação de Mestrado em Arte Contemporânea. Universidade de Brasília, 2010.

KEMP, Jonathan. Decrystallization/Descristalização. In: BORGES, Fabiane M. (Org.). Peixe morto. Submidialogias, 2012, pp. 94-100.

LÉVI-STRAUSS, Claude. O pensamento selvagem. Campinas: Papirus, 1989. 
LOPES, Aurea. Celebração do bem comum: redes transitam do virtual para o espaço público na terceira edição do CulturaDigital.br, no Rio de Janeiro. ARede, n.77, 2012. Disponível em: <http://www.revista.arede.inf.br/site/edicao-n-77-janeiro-2012/4970-cultura-celebracao-do-bem-comum-edicao-77>. Acesso em: 06 out. 2016.

LOVINK, Geert. Just Out: Digitofagia-Brazilian Tactical Media Anthology. Institute of Network Cultures, 2009. Disponível em: <http://networkcultures.org/ geert/2009/01/29/just-out-digitofagia-brazilian-tactical-media-anthology/>. Acesso em: 06 out. 2016.

Panic Content - The ZKP 3 Introduction Draft (october 1996). Nettime, 1998. Disponível em: <http://nettime.org/Lists-Archives/nettime-l-9804/msgooo25. html>. Acesso em: 06 out. 2016.

MEIRELES, Adriana V. Pontos de Cultura, novas mídias, educação e democracia: reflexões sobre o contexto de uma mudançaestrutural no Brasil. In: BRUNET, Karla S. (Org.). Apropriações tecnológicas: emergência de textos, idéias e imagens do Submidialogia\#3. Salvador: EDUFBA, 2008, pp. 35-41.

METÁ:FORA. Os primórdios da MetaReciclagem. In: FONSECA, Felipe. (Ed.). História da MetaReciclagem, histórias de MetaReciclagem. São Paulo: metareciclagem. org, 2009, pp. 31-9.

MUTGAMB. O que Wiqua nos reserva para este MutSaz... MutSaz, Outono, 2011. Disponível em: <http://mutgamb.org/MutSaz/2011/Wiqua>. Acesso em: o6 out. 2016.

NOVAES, Thiago. Tecnomagia: metareciclagem e rádios livres no front de uma guerra ontológica. Fórum Permanente, v.2, n.2, 2013. Disponível em: <http://www.forumpermanente.org/revista/numero-2/textos/tecnomagia>.

PÁDUA, Daniel. Manifesto Nartisan: o artesão das redes. Mutirão da Gambiarra. 2009. Disponível em: <http://mutgamb.org/fonte/Manifesto-nartisan>. Acesso em: o6 out. 2016.

PIGNATARI, Décio. Depoimento 2. In: Contracomunicação. Cotia: Ateliê Editorial, 2004, pp. 31-2.

ROSAS, Ricardo. Gambiarra: alguns pontos para se pensar uma tecnologia recombinante. Caderno Videobrasil, n.2, 2006, pp. 36-53.

ROSAS, Ricardo; VASCONCELOS, Giseli. (Orgs.). Net_cultura 1.o: Digitofagia. São Paulo: Radical Livros, 2006.

SISA, Bartolina. Manifesto para a engenharia reversa das redes. Outras Palavras: comunicação compartilhada e pós-capitalismo, 2011. Disponível em: <http:// outraspalavras.net/posts/manifesto-para-a-engenharia-reversa-de-nossas-redes/>. Acesso em: 06 out. 2016. 
SOARES, Guilherme. Yupana. Jardins de Volts: esporos de pesquisa e experimentação. 2012. Disponível em: <http://wiki.devolts.org/w/index.php?title=Yupana >. Acesso em: 06 out. 2016.

SOLER, Pedro. Magia e tecnologia. In: BELISÁRIO, (Feitosa da Costa), Adriano. (Org.). Tecnomagia. Rio de Janeiro: Imotirõ, 2016, pp.8-47.

SWENSON, Olav (Eduardo Pinheiro). Memórias do Neto de Dacum, o Aborígene (outrora intitulado "ciber\%amanismo"). Porto Alegre, 2014.

VIDAL JR., Icaro F. Encantamento é acaso descolonizado/Enchantment is decolonized chance. In: NATÁLIO, Rita e LEVI, Joana (Orgs.). Museu encantador: uma coleção temporária de encantos permanentes de Brasil e Portugal. São Paulo: Caixa Cultural, 2016, pp. 56-61.

VIVEIROS DE CASTRO, Eduardo B. A inconstância da alma selvagem e outros ensaios. São Paulo: Cosac \& Naify, 2002.

WELLS, Tatiana. Descolonizar - Laboratório de Cartografias Insurgentes. In: VASCONCELOS, Giseli. (Org.). Por uma cartografia crítica da Amazônia: recorte/processo sobre arte, política e tecnologias possíveis. dossiê.comumlab. org, 2012, pp.57-8.

WELLS, Tatiana; BRAZILEIRO, Ricardo; TARIN, Bruno. Tecnoxamanismo digitofágico - Pós LabSurLab: que venga el Sur! Revista Global Brasil, n.14, 2011. Disponível em: <http://www.revistaglobalbrasil.com.br/?p=695>. Acesso em: 06 out. 2016.

WELLS, Tatiana; RUIZ, Ricardo. (Orgs.). Digitofagia cu-que-buquê (cook book). São Paulo: midiatatica.info, 2006. Disponível em: <http://desarquivo.org/sites/default/ files/digitografia_cu-que-bu-que.pdf $>$. Acesso em: 06 out. 2016.

Recebido em 01/06/2016

Aprovado em 30/06/2016

\section{Como citar este artigo:}

COSTA, Adriano Belisário Feitosa da; Eliska. FERREIRA, Pedro P. Perspectivas tecnoxamânicas e tecnomágicas no ativismo digital brasileiro recente: uma trajetória possível . Contemporânea - Revista de Sociologia da UFSCar, v. 6, n. 2, jul.-dez. 2016, pp. $335-367$. 